\title{
Occurrence of Beet black scorch virus Infecting Sugar Beet in Europe
}

Magali González-Vázquez, Departamento de Biotecnología and Centro de Biotecnología y Genómica de Plantas, Universidad Politécnica de Madrid, 28040 Madrid, Spain; Julián Ayala, Asociación de Investigación y Mejora del Cultivo de la Remolacha Azucarera, Ctra. De Villabañez Km 2.7, 47012 Valladolid, Spain; and Fernando GarcíaArenal and Aurora Fraile, Departamento de Biotecnología and Centro de Biotecnología y Genómica de Plantas, Universidad Politécnica de Madrid, 28040 Madrid, Spain

\section{ABSTRACT \\ González-Vázquez, M., Ayala, J., García-Arenal, F., and Fraile, A. 2009. Occurrence of Beet black scorch virus infecting sugar beet in Europe. Plant Dis. 93:21-24.}

In a survey of soilborne viruses infecting sugar beet in central Spain, Beet black scorch virus (BBSV) was detected in field grown sugar beets with symptoms of rhizomania disease. BBSV was found in all analyzed sugar beet producing regions from central Spain, as well as in bait plants grown in soils with a history of rhizomania from several Western European countries, thereby constituting the first report of BBSV in Europe. BBSV was transferred to Chenopodium quinoa, where it caused chlorotic local lesions from which virus particles were purified. The nucleotide sequence of the 3'-untranslated region of the genomic RNA was determined for 13 European isolates, and sequences were highly similar to those reported for Chinese and U.S. isolates. Sequence comparisons revealed three clusters of sequences, one including most European isolates, one including one European and two Chinese isolates, and the third including the U.S. isolate. BBSV was detected in a number of samples with rhizomania symptoms in which Beet necrotic yellow vein virus went undetected. However, its role in rhizomania disease in Europe, if any, remains to be established.

Additional keywords: Necroviruses

Diseases caused by soilborne viruses, particularly by those persistently transmitted by plasmodiophorid and chytrid vectors, are a serious threat to field crops worldwide. This is the case of rhizomania of sugar beet, caused by the benyvirus Beet necrotic yellow vein virus (BNYVV), which is persistently transmitted by the plasmodiophorid Polymyxa betae (18). Rhizomania is a limiting factor for sugar beet production, and in soils infested by BNYVV and its vector, only resistant cultivars can be grown with an acceptable yield. Sources of resistance to BNYVV have been found in Beta vulgaris subsp. maritima, and cultivars of sugar beet partially resistant to BNYVV have been developed by introgression of the genes $R z 1$ and $R z 2$ (7). Although these resistant cultivars give adequate protection in most regions, there is serious concern about the possibility of the appearance and dispersion of BNYVV strains able to overcome the existing resistance factors. Until now, BNYVV isolates able to cause rhizomania symptoms on resistant $(R z 1)$ cultivars have

Corresponding author: Aurora Fraile

E-mail: aurora.fraile@upm.es

Accepted for publication 9 September 2008.

doi:10.1094/PDIS-93-1-0021

(C) 2009 The American Phytopathological Society been reported in Europe and Asia, associated with the presence of satellite-like RNA5 $(6,10,11)$. In the United States, the ability to overcome the same resistance appears to be associated with mutations in the RNA3-encoded p25 protein $(1,14,15)$.

Other $P$. betae-transmitted viruses infecting sugar beet are Beet soil-borne virus (BSBV) and Beet virus Q (BVQ), both belonging to the genus Pomovirus, which have been reported in Europe, including Spain $(12,13,17,20)$, and Beet soil-borne mosaic virus (genus Benyvirus), which has only been reported in North America (18). These viruses have no demonstrated role in rhizomania disease $(16,18)$. In addition, a sugar beet-infecting virus, Beet black scorch virus (BBSV, genus Necrovirus, family Tombusviridae), was reported in China, and two isolates have been characterized molecularly $(3,4)$. BBSV is transmitted by Olpidium brassicae zoospores (8) and is reported to cause black scorch of leaves and necrosis of roots $(2,5)$. In China, a satellite RNA (BBSV-satRNA) has been found associated with BBSV isolates from Xinjian Province (5), but it has not been found in association with BBSV from other areas. Recently, BBSV has been reported in the United States, isolated from sugar beet plants with rhizomania-like symptoms, and a U.S. isolate has been molecularly characterized $(22,23)$.

In Spain, rhizomania is an important disease of sugar beet crops in the northern and southern central plateau, where beet is planted in spring and harvested in winter. Resistant cultivars account for greater than $90 \%$ of the crop in these areas, and usually perform well both in the presence and in the absence of rhizomania disease. During the last 3 years in some areas of the southern central plateau, however, rhizomanialike symptoms were apparent in BNYVVresistant cultivars. This prompted us to reanalyze the distribution of BNYVV and of other soilborne viruses infecting sugar beet in Spain. Information on the distribution of BSBV and BVQ in Spain was available (17), but this was not the case for BBSV. In the course of this survey, BBSV was detected in sugar beets from Spain, as well as in soils from other European countries with a history of sugar beet production. Thus, we report here the first detection of BBSV in Europe. Comparison of the nucleotide sequence of the $3^{\prime}$-untranslated region ( $3^{\prime}$-UTR) suggests at least three clusters of BBSV isolates worldwide.

\section{MATERIALS AND METHODS}

Samples. Field-grown sugar beet plants with rhizomania symptoms from different locations in central Spain were collected, and sugar beet soils were obtained from different European countries, all with a history of rhizomania. The origins of Spanish sugar beet plants and European soils are described in Table 1.

Two 200-ml (6 cm diameter) pots were filled with a sample of each of the European soils, and five sugar beet seedlings cv. Orbis (Strube-Dieckmann, Germany) were planted in each pot. The cultivar Orbis is registered in Spain as a genetic monogerm and is susceptible to rhizomania. This variety has been used by AIMCRA (Asociación de Investigación y Mejora del Cultivo de la Remolacha Azucarera, private sugar beet research institute) in field assays for the past 8 years as a susceptible control in tests for resistance to rhizomania because of its susceptibility and adaptation to Spanish conditions. The pots were placed in separate trays for each sample set, and the soil was kept moist during the 2 months prior to sampling.

Detection of BNYVV and BBSV. The lateral roots of sugar beet or roots of bait plants were washed with running tap water, the rootlets were collected, and total 
nucleic acids (TNA) were extracted from $200 \mathrm{mg}$ of rootlets using Tri Reagent (Sigma Chemical Co., St. Louis, MO) according to the manufacturer's protocol. The presence of BNYVV and of BBSV was analyzed by reverse transcriptionpolymerase chain reaction (RT-PCR). For RT-PCR detection of BNYVV, the primers described in Meunier et al. (16), which amplify a 545-bp fragment from RNA2, were used. For BBSV detection, the primers used were identical to nucleotides
3341-3370 of BBSV genomic RNA (BBSV3UTRfwd) and complementary to the $3^{\prime}$ terminal 27 nucleotides (positions 3618-3644) (BBSV3rev) (nucleotide position numbers refer to sequence AF452884), as suggested by J. Weiland (personal communication). The primers amplify a 303-bp fragment including the 299 nt 3'-UTR of BBSV-RNA. For detection of BBSV, sat RNA primers BB-S3 and BB-S7 as described in Guo et al. (5) were employed. Positive controls were sugar

Table 1. Origin of the samples tested and presence of Beet necrotic yellow vein virus (BNYVV) and Beet black scorch virus (BBSV) in the roots of sugar beets sown in different soils

\begin{tabular}{lccc}
\hline & & \multicolumn{2}{c}{ Presence of $^{\mathbf{a}}$} \\
\cline { 3 - 4 } Origin & Sample & BNYVV & BBSV \\
\hline North central Spain & & & 2 \\
Pampliega (Burgos) & Bu-Pm & 0 & 1 \\
Laguna de Negrillos (León) & Le-LN & 1 & 1 \\
Pobladura (León) & Le-Pb & 0 & 2 \\
Nava del Rey (Valladolid) & Va-NR & 0 & 4 \\
Laguna (Valladolid) & Va-Lg & 0 & 5 \\
Bercero (Valladolid) & Va-Be & 0 & 1 \\
South central Spain & & & 1 \\
Daimiel (Ciudad Real) & CR-Dm1 & 2 & 1 \\
Daimiel (Ciudad Real) & CR-Dm2 & 4 & 0 \\
Aguas Nuevas (Albacete) & Ab-AN & 1 & $1 / 1$ \\
Minaya (Albacete) & Ab-My & 1 & $2 / 2$ \\
La Roda (Albacete) & Ab-Rd & 3 & $1 / 2$ \\
Europe & & & $1 / 3$ \\
United Kingdom B & GB-B & $1 / 1$ & $1 / 1$ \\
United Kingdom K & GB-K & $2 / 2$ & $3 / 3$ \\
Italy C & IT-C & $0 / 3$ & $2 / 3$ \\
Italy CP & IT-CP & $0 / 3$ & \\
France & FR2 & $1 / 1$ & $2 / 3$ \\
Germany & D1 & $3 / 3$ & \\
The Netherlands & NL1 & & \\
\hline
\end{tabular}

${ }^{\text {a }}$ For samples from Spain, data are number of positive plants in reverse transcription-polymerase chain reaction (RT-PCR) analyses per five tested plants per site. For European soils, data indicate the reaction, positive or negative, in RT-PCR, in extracts of five pooled plants per pot per number of analyzed plots. The number of pots varied with soil availability. RT-PCR for BBSV and BNYVV were done using the primers described in Materials and Methods. beet roots experimentally infected with BNYVV pathotype A and a plasmid containing the $3^{\prime}$-UTR of the U.S. isolate of BBSV, the kind gifts of Claude Bragard (Université Catholique de Louvain, Louvain-la-Neuve, Belgium) and J. Weiland (USDA-ARS, Fargo, ND, USA), respectively.

BBSV sequence. The nucleotide sequence of the $3^{\prime}$-UTR of BBSV RNA was determined from the RT-PCR amplicons obtained with primers BBSV3UTRfwd and BBSV3rev (Secugen S.L., Madrid, Spain). The 3'-UTR nucleotide sequence was determined for all the isolates from soil samples of other European countries that were positive for BBSV, as well as for three randomly selected isolates from each of the two sugar beet-growing areas of central Spain. The resulting sequences, together with those available from published isolates (accession numbers AY626780, $\mathrm{AF} 452884$, and EF153268), were aligned using CLUSTAL X (21). Genetic distances between sequences were obtained using Kimura's two parameter method (9), and the distance matrix was used to determine relationships among the isolates using the neighbor-joining method (19).

BBSV characterization. BBSV from field-infected sugar beet roots was purified according to Guo et al. (5) with modifications: $50 \mathrm{~g}$ of washed roots were ground at $4^{\circ} \mathrm{C}$ in 2 volumes of $0.1 \mathrm{M}$ phosphate buffer, $\mathrm{pH} 7.0,1$ volume of chloroform, and $1 \% 2$-mercaptoethanol. The slurry was centrifuged at $7,900 \times g$ for $10 \mathrm{~min}$, and the supernatant was centrifuged at 145,000 $\times g$ for $90 \mathrm{~min}$. The pellet was resuspended overnight in $0.02 \mathrm{M}$ phosphate buffer, $\mathrm{pH}$ 7.0. The resulting preparation was used to inoculate Chenopodium quinoa leaves. Four days after inoculation, BBSV particles
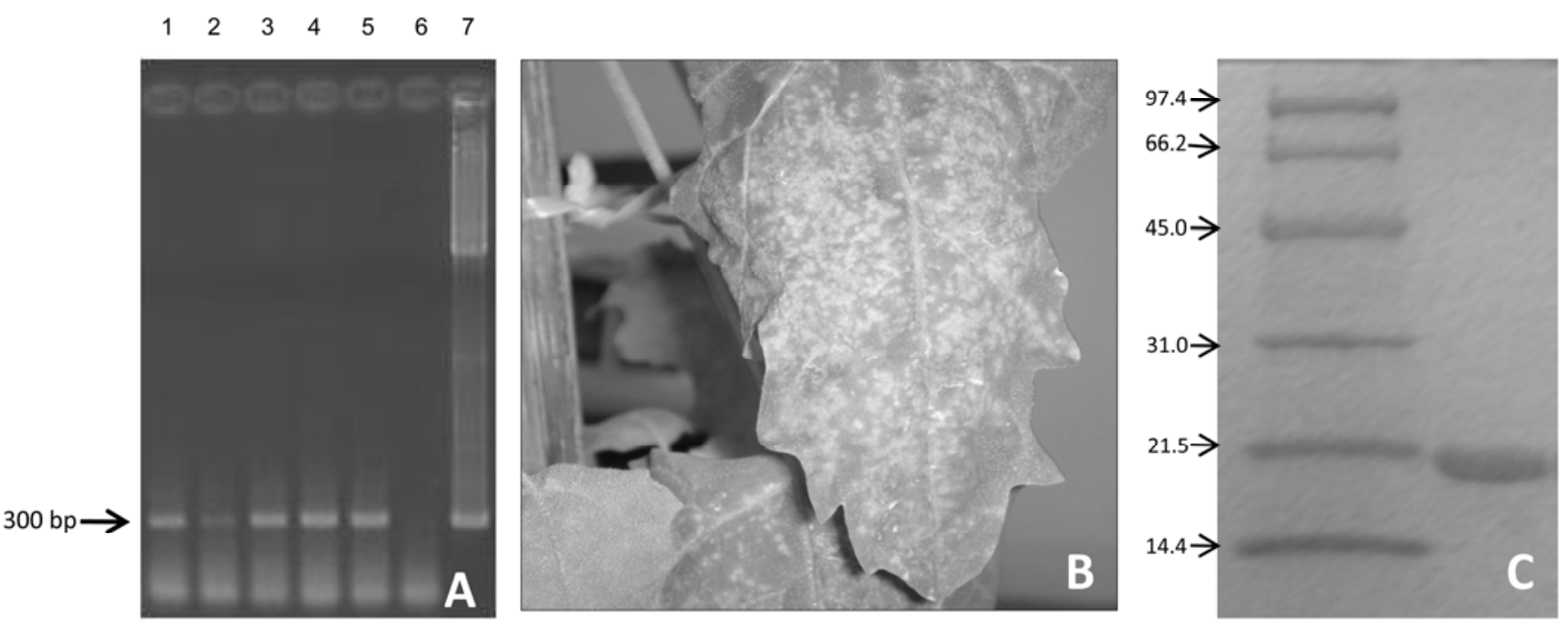

Fig. 1. Detection and characterization of Beet black scorch virus (BBSV) from Europe. A, Reverse transcription-polymerase chain reaction (RT-PCR) with primers for BBSV detection in nucleic acid extracts from beet samples from Spain (1: Va-Be, 2: CR-Dm1, 3: Le-LN, and 6: Ab-Rd) and other European countries (4: IT-CP, 5: GB-B). 7: Positive control. B, Local lesions in Chenopodium quinoa leaves at 4 days postinoculation with virion preparations from sugar beet roots of sample Va-Be. C, Sodium dodecyl sulfate-polyacrylamide gel electrophoresis (SDS-PAGE) of proteins in viral particles purified from $C$. quinoa leaves. Unstained SDS-PAGE standards (left) were: 97.4 kDa: Phosphorylase b; $66.2 \mathrm{kDa}$ : Bovine serum albumin; $45 \mathrm{kDa}$ : Ovalbumin; $31 \mathrm{kDa}$ Carbonic anhydrase; $21.5 \mathrm{kDa}$ : Trypsin inhibitor; $14.4 \mathrm{kDa}$ : Lysozyme. 
were purified from $C$. quinoa leaves, virion RNA was extracted in $0.02 \mathrm{M}$ Tris, $\mathrm{pH} 8.5$, $0.02 \mathrm{M} \mathrm{NaCl}, 5 \mathrm{mM}$ EDTA, $1 \%$ sodium dodecyl sulfate (SDS), maintained at $60^{\circ} \mathrm{C}$ for $5 \mathrm{~min}$, and extracted twice with phenol:chloroform (1:1). The RNA was used as a template for RT-PCR with the primers used for BBSV detection (BBSV3UTRfwd and BBSV3rev). To determine the molecular weight (MW) of the capsid protein, purified BBSV particles from $C$. quinoa were disrupted in $50 \mathrm{mM}$ Tris, $\mathrm{pH} 6.8,2 \%$ SDS, $5 \%$ 2-mercaptoethanol, $10 \%$ glycerol, and $0.1 \%$ bromophenol blue at $95^{\circ} \mathrm{C}$ for $3 \mathrm{~min}$, and proteins were analyzed by denaturing $12 \%$ SDS-polyacrylamide gel electrophoresis (PAGE) and staining with Coomassie Brilliant Blue R-250. To estimate the MW of the protein, unstained SDS-PAGE standards were used (Bio-Rad, Hercules, CA, USA).

\section{RESULTS AND DISCUSSION}

BNYVV was detected in roots of fieldgrown plants from all analyzed sites in southern central Spain, and from one out of six analyzed sites in northern central Spain (Table 1). BNYVV was also detected in roots from bait plants grown in soils from various European countries, except those from Casale and Copparo (Italy) (Table 1). BBSV was detected in most analyzed samples, with the exception of those from La Roda (Albacete, Spain) (Table 1), showing the widespread distribution of this virus in sugar beet growing areas from central Spain and, possibly, in the rest of the European countries from which soils were analyzed. In all cases, RT-PCR resulted in the amplification of a band of $303 \mathrm{bp}$, as expected from the nucleotide sequence of BBSV RNA from China (Fig. 1A). BBSV-satRNA was not detected in any of the samples that were positive for BBSV (not shown).

The nucleotide sequence of the $3^{\prime}$-UTR of BBSV RNA was determined from the RT-PCR amplicons for three randomly chosen sites in northern central Spain (Le-Pb, Acc. No. AM941660; Le-LN,
Acc. No. AM941659; and Va-Be, Acc. No. AM941661), three randomly chosen sites in southern central Spain (CR-Dm1, Acc. No. AM941662; CR-Dm2, Acc. No. AM941663; and Ab-My, Acc. No. AM941658), and for all sites in other European countries where the virus was detected (samples D1, Acc. No. AM941669; NL1, Acc. No. AM941670; GB-B, Acc. No. AM941664; GB-K, Acc. No. AM941665; Fr-2, Acc. No. AM941668; IT-C, Acc. No. AM941666; and IT-CP, Acc. No. AM941667). The comparison between the nucleotide sequences (not shown) revealed limited nucleotide diversity, with nucleotide identity $\geq 97 \%$. It should be pointed out that this degree of nucleotide identity is within the range of that between the reported sequences for three BBSV isolates, two from Ningxia and Xingjiang provinces in China (accession numbers AY626780 and AF452884) and one from the United States (accession number EF153268), which is $97.32 \%$, suggesting that the $3^{\prime}-\mathrm{UTR}$ is

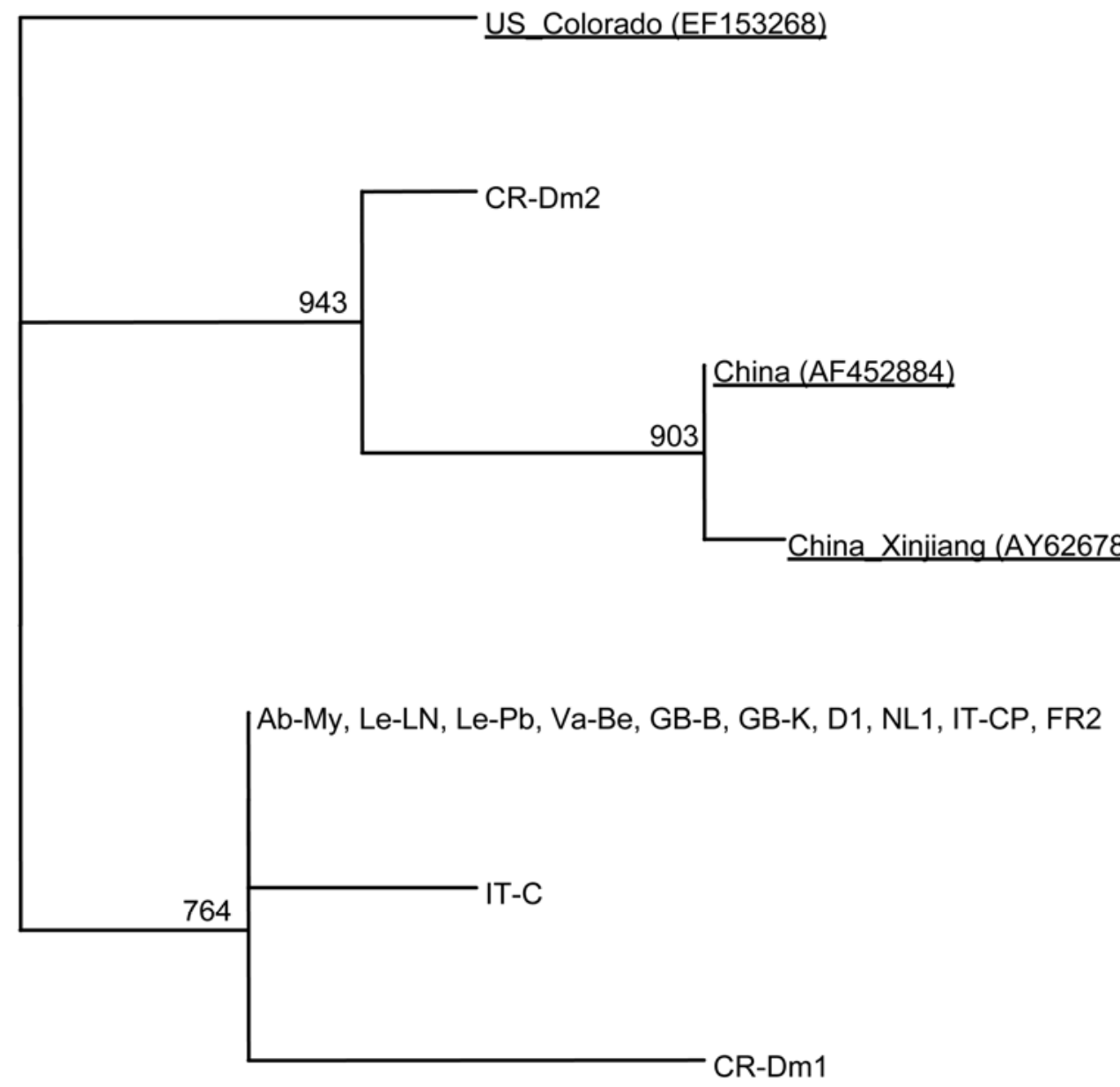

0.01

Fig. 2. Neighbor-joining tree for sequences of the $3^{\prime}$-untranslated region (3'-UTR) of Beet black scorch virus (BBSV) isolates from Europe. The significance of the nodes in a bootstrap analysis with 1,000 replicates is shown. 3'-UTR sequences from U.S. (EF153268) and Chinese (AF452884, AY626780) isolates are identified by their origin and EMBL data bank accession numbers. 
highly conserved in BBSV RNA. The dendrogram resulting from the analysis of the 3'-UTR sequences by the neighborjoining method (19) showed three significant clusters (Fig. 2): one included the two sequences from China and the sequence from one site in southern central Spain (CR-Dm2), a second cluster included the sequence from the United States, and a third included most sequences from Europe. Thus, on the basis of the 3'-UTR, three putative strains can be defined for BBSV, which we name here the European, U.S., and Chinese. Comparison of $299 \mathrm{nt}$ within the 3'-UTR of the three strains identified 19 polymorphic positions. Four of these are specifically associated with the U.S. strain, four are associated with the Chinese strain, and one is associated with the European strain. This means that between the putative U.S. and Chinese strains, there are 8 specific differences, and 5 specific differences between the European and U.S. or the European and Chinese putative strains. Nucleotide identities within each strain were greater than 99\% within this region of the genome. Both European and Chinese strains are present in Europe, with an apparent higher prevalence of the first strain based on data presented herein.

To partially characterize a BBSV isolate from Europe, BBSV from sample Va-Be was chosen. Sugar beet roots positive for BBSV from this site were negative for BNYVV. BBSV purified from fieldinfected sugar beet roots was used to inoculate $C$. quinoa leaves. After 4 days in a greenhouse at 20 to $25^{\circ} \mathrm{C}$ and a 16-h light period, inoculated leaves showed abundant chlorotic local lesions (Fig. 1B); at this time, no systemic symptoms were observed. Nucleic acid extracts from infected $C$. quinoa leaves were negative for BNYVV, as well as for BSBV and BVQ (not shown), and positive for BBSV in RTPCR assays. Viral RNA was extracted from BBSV particles purified from $C$. quinoa leaves, and was used as a template for RTPCR with the primers described previously for BBSV detection. The nucleotide sequence from the amplified fragment was $100 \%$ identical to that obtained from the nucleic acid extracts from the fieldinfected sugar beet (not shown). Disrupted purified BBSV particles showed a single band with an apparent molecular weight around $21 \mathrm{kDa}$ when analyzed by SDSPAGE under reducing conditions (Fig. 1C), which is in line with the molecular size deduced for the 24.4-kDa coat protein (CP) from the nucleotide sequences of Chinese and U.S. isolates (23). Interestingly, oligonucleotide primers based on previously reported BBSV sequences have failed to amplify the CP gene of any "isolate" from Europe (not shown), suggesting a higher diversity at this genomic region, in agreement with the observation that this region has the lowest level of nucleotide sequence conservation in open reading frame (ORF) comparisons between BBSV isolates (23). The nucleotide identities in the CP ORF for the three BBSV sequences in the GenBank database are $99.6 \%$ between the two Chinese isolates and $91 \%$ between the Chinese and U.S. isolates, the latter of which are the lowest genetic conservation for any ORF of BBSV.

In summary, our results show that BBSV, unreported until now in Europe, is widespread in soils of Western Europe with a history of sugar beet cultivation. Two putative strains of BBSV appear to be present in Europe, based on comparison of sequences within the $3^{\prime}$-UTR sequence, albeit with broadly different prevalence. The U.S. isolate of BBSV was obtained from sugar beet plants with rhizomanialike symptoms from which BNYVV and BSBMV were not detected (23). Similarly, in this work, BBSV was detected in roots of European sugar beet plants with rhizomania-like symptoms from which BNYVV was also unable to be detected. The presence of BBSV in association with these symptoms does not indicate any clear role for BBSV in inducing rhizomania-like symptoms, and further research will be necessary to clarify the nature of this association.

\section{ACKNOWLEDGMENTS}

This work was in part supported by contract P070210-071 between AIMCRA and Departamento de Biotecnología, UPM. We thank Mike Asher (Broom's Barn Research Centre, UK), Hans Schneider (Institute of Sugar Beet Research-IRS, The Netherlands), Mark Varrelmann (Institut für Zuckerrübenforschung - IFZ, Germany), Marc Richard-Molard (Institut Technique Français de la Betterave Industrielle-ITB, France), and Nicola Minerva (Società Italiana per la ricerca e la sperimentazione in Bieticoltura - Beta S.C.ar. L., Italy) for sending soil samples, and Claude Bragard and J. Weiland for providing positive controls for the detection of BNYVV and BBSV. Begoña Prieto provided excellent technical assistance.

\section{LITERATURE CITED}

1. Acosta-Leal, R., and Rush, C. M. 2007. Mutations associated with resistance-breaking isolates of Beet necrotic yellow vein virus and their allelic discrimination using TaqMan technology. Phytopathology 97:325-330

2. Cao, Y., Cai, Q., Ding, Q., Li, D., Han, C., Yu, J., and Liu, Y. 2002. The complete nucleotide sequence of Beet black scorch virus (BBSV), a nex member of the genus Necrovirus. Arch. Virol. 147:2431-2435.

3. Cui, X. M. 1988. An icosahedral virus found in sugar beet. J. Xinjiang Shihezi Agric. Coll. 10:73-78

4. Cui, X. M., Cai, Z. N., Wu, J., and Liu, Y. 1991. Study on symptom pattern of sugarbeet rhizomania disease. Plant Prot. 17:5-7.

5. Guo, L. H., Cao, Y. H., Li, D. W., Niu, S. N., Cai, Z. N., Han, C. G., Zhai, Y. F., and Yu, J. L. 2005. Analysis of nucleotide sequences and multimeric forms of a novel satellite RNA associated with Beet black scorch virus. J. Virol. 79:3664-3674.

6. Harju, V. A., Mumford, R. A., Bockley, A., Boonham, N., Clover, G. R. G., Weekes, R., and Henry, C. M. 2002. Occurrence in the United Kingdom of beet necrotic yellow vein virus isolates which contains RNA5. Plant Pathol. 51:811.

7. Heijbroek, W., Musters, P. M. S., and Schoone, A. H. L. 1999. Variation in pathogenicity and multiplication of beet necrotic yellow vein virus (BNYVV) in relation to the resistance in sugar-beet cultivars. Eur. J. Plant Pathol. 105:397-405.

8. Jiang, J. X., Zhang, J. F., Che, S. Ch., Yang, D. J., Yu, J. L., Cai, Z. N., and Liu, Y. 1999 Transmission of beet black scorch virus by $\mathrm{Ol}$ pidium brassicae. J. Jiangxi Agric. Univ. 21:525-528.

9. Kimura, M. 1980. A simple method for estimating evolutionary rate of base substitutions through comparative studies of nucleotide sequences. J. Mol. Evol. 16:111-120.

10. Koenig, R., Haeberlé, A.-M., and Commandeur, U. 1997. Detection and characterization of a distinct type of beet necrotic yellow vein virus RNA 5 in a sugerbeet growing area in Europe. Arch. Virol. 142:1499-1504.

11. Koenig, R., and Lennefors, B.-L. 2000. Molecular analyses of European A, B, and P type sources of Beet necrotic yellow vein virus and detection of the rare $\mathrm{P}$ type in Kazakhstan. Arch. Virol. 145:1561-1570.

12. Koenig, R., Pleij, A., Beier, C., and Commandeur, U. 1998. Genome properties of beet virus $\mathrm{Q}$, a new furo-like virus from sugarbeet, determined from unpurified virus. J. Gen. Virol. 79:2027-2036.

13. Lennefors, B.-L., Savenkov, E. I., Mukasa, S. B., and Valkonen, J. P. T. 2005. Sequence divergence of four soilborne sugarbeet-infectin viruses. Virus Genes 31:57-64.

14. Liu, H.-Y., and Lewellen, R. T. 2007. Distribution and molecular characterization of resistance-breaking isolates of Beet necrotic yellow vein virus in the United States. Plant Dis. 91:847-851.

15. Liu, H.-Y., Sears, J. L., and Lewellen, R. T. 2005. Occurrence of resistance-breaking Beet necrotic yellow vein virus of sugar beet. Plant Dis. 89:464-468.

16. Meunier, A., Schmit, J. F., Stas, A., Kutluk, N., and Bragard, C. 2003. Multiplex reversetranscription_PCR for simultaneous detection of Beet necrotic yellow vein virus, Beet Soilborne virus, and Beet virus $Q$ and their vector Polymyxa betae KESKIN on sugar beet. Appl. Environ. Microbiol. 69:2356-2360.

17. Rubies Autonell, C., Ratti, C., Resca, R., De Biaggi, M., and Ayala Garcia, J. 2006. First report of Beet virus $Q$ in Spain. Plant Dis. 90:110.

18. Rush, C. M. 2003. Ecology and epidemiology of Benyviruses and plasmodiophorid vectors. Annu. Rev. Phytopathol. 41:567-592.

19. Saitou, N., and Nei, M. 1987. The neighborjoining method, a new method for reconstructing phylogenetic trees. Mol. Biol. Evol. 4:406425.

20. Schirmer, A., Link, D., Cognat, V., Moury, B., Beuve, M., Meunier, A., Bragard, C., Gilmer, D., and Lemaire, O. 2005. Phylogenetic analysis of isolates of Beet necrotic yellow vein virus collected worldwide. J. Gen. Virol 86:2897-2911.

21. Thompson, J. D., Gibson, T. J., Plewniak, F., Jeanmougin, F., and Higgins, D. G. 1997. The ClustalX windows interface: Flexible strategies for multiple sequence alignment aided by quality analysis tools. Nucleic Acids Res. 25:4876-4882.

22. Weiland, J. J., Larson, R. L., Freeman, T. P. and Edwards, M. C. 2006. First report of Beet black scorch virus in the United States. Plant Dis. 90:828.

23. Weiland, J. J., Van Winkle, D., Edwards, M. C., Larson, R. L., Shelver, W. L., Freeman, T. P., and Liu, H.-Y. 2007. Characterization of a U.S. isolate of Beet black scorch virus. Phytopathology 97:1245-1254. 